\title{
Behavioral adaptations in Ameivula ocellifera (Squamata: Teiidae) in response to thermal environmental changes
}

\author{
Raul Fernandes Dantas Sales and Eliza Maria Xavier Freire
}

Laboratório de Herpetologia, Departamento de Botânica e Zoologia, Universidade Federal do Rio Grande do Norte, Natal, RN, 59078-970, Brazil. E-mails: raulsales17@gmail.com, elizajuju1000@ gmail.com.

\begin{abstract}
Behavioral adaptations in Ameivula ocellifera (Squamata: Teiidae) in response to thermal environmental changes. Lizards rely on external sources to regulate body temperature, but in many species, it is not known whether lizards are able to change their thermoregulatory behaviors in response to variations in thermal environments. The seasonal thermal ecology of three populations of the Brazilian whiptail lizard, Ameivula ocellifera, in northeastern Brazil (two Caatinga sites and one in the Atlantic Forest) was investigated. The relationships between body temperature and microhabitat temperatures (substrate and air), and between body temperature and thermoregulatory behavior (i.e., time of exposure to sunlight classes and time spent basking) were explored. The average body temperatures of the lizards were $38-39^{\circ} \mathrm{C}$; these neither varied seasonally nor among populations. Substrate and air temperatures are lower at the natural Caatinga site, and lizards in there spent less time in the shade and more time exposed to the sun. Microhabitat temperatures vary seasonally in natural Caatinga; they are lower in the rainy season, when lizards spent more time exposed to sun and less time in filtered sun. Lizard body temperatures exceeded microhabitat temperatures in the rainy season in all three populations; however, they did not exceed substrate temperature in the dry season. In each of the populations, lizards with low body temperatures during cloudy conditions spent more time basking. Thus, $A$. ocellifera adjusts its body temperature behaviorally to compensate for seasonal changes in environmental temperatures, as well as geographic thermal variation throughout its range.
\end{abstract}

Keywords: body temperature, lizards, seasonality, thermal ecology, thermoregulatory behavior.

\section{Resumo}

Adaptações comportamentais em Ameivula ocellifera (Squamata: Teiidae) em resposta a mudanças térmicas ambientais. Lagartos usam fontes externas para regular a temperatura corpórea, mas em muitas espécies não é conhecido se os lagartos são capazes de mudar seus comportamentos

Received 16 April 2019

Accepted 19 September 2019

Distributed December 2019 
termorregulatórios em resposta a variações nos ambientes térmicos. A ecologia térmica sazonal de três populações do lagarto cauda-de-chicote brasileiro, Ameivula ocellifera, no nordeste do Brasil (duas áreas na Caatinga e uma na Mata Atlântica) foi investigada. As relações entre a temperaturas corpóreas e as temperaturas do microhabitat (substrato e ar), e entre a temperatura corpórea e o comportamento termorregulatório (i.e. tempo de exposição às classes de luminosidade e tempo gasto em aquecimento termorregulatório) foram exploradas. Os valores médios das temperaturas corpóreas dos lagartos foram $38-39^{\circ} \mathrm{C}$; estes não variaram sazonalmente nem entre populações. As temperaturas do substrato e do ar são menores na área de Caatinga natural, e os lagartos desta área passaram menos tempo na sombra e mais tempo expostos ao sol. As temperaturas do microhabitat variam sazonalmente na Caatinga natural; são mais amenas na estação chuvosa, quando os lagartos passaram mais tempo expostos ao sol e menos tempo no sol filtrado. As temperaturas corpóreas dos lagartos excederam as temperaturas do microhabitat na estação chuvosa em todas as três populações; entretanto, elas não excederam a temperatura do substrato na estação seca. Em cada população, lagartos com temperaturas corpóreas baixas durante condições nubladas passaram mais tempo em aquecimento termorregulatório. Deste modo, A. ocellifera ajusta sua temperatura corpórea através do comportamento para compensar mudanças sazonais nas temperaturas ambientais, bem como compensar a variação térmica ao longo da sua amplitude geográfica de ocorrência.

Palavras-chave: comportamento termorregulatório, ecologia térmica, lagartos, sazonalidade, temperatura corpórea.

\section{Introduction}

Body temperatures of ectotherms affect overall organismal functions and are influenced by thermal conditions (Kohlsdorf and Navas 2006, Rocha et al. 2009). Lizards depend on external sources to regulate body temperatures (Bogert 1949, Huey and Slatkin 1976). Besides being affected by extrinsic factors such as sunlight (Patterson and Davies 1978, Stevenson 1985), intensity of winds (Maia-Carneiro et al. 2012, 2017), and daily and seasonal changes of environmental temperatures (Peloso et al. 2008, Ribeiro and Freire 2010, Menezes and Rocha 2011), body temperatures $\left(T_{b}\right)$ of lizards are influenced by intrinsic factors such as ontogeny and body size (Stevenson 1985, Magnusson 1993, Maia-Carneiro and Rocha 2013a). Furthermore, $\mathrm{T}_{\mathrm{b}}$ is a function of evolutionary relationships-i.e., closely related species or different populations of a given species tend to have similar $\mathrm{T}_{\mathrm{b}}$, despite environmental differences (Bogert 1949, Andrews 1998, Menezes and Rocha 2011, Sales et al. 2011). Although physiological adjustments contribute to lizard thermoregulation, behavior is the primary way in which lizards regulate their body temperature (Bauwens et al. 1996). Thermoregulating lizards move between shaded, colder and sunny, warmer sites; they regulate daily times of activity, and modify postures to increase or decrease body surfaces exposed to thermal sources (Huey and Pianka 1977, Schall 1977, Heatwole and Taylor 1987).

Studies on thermal ecology of lizards typically have analyzed relationships between $\mathrm{T}_{\mathrm{b}}$ and microhabitat temperatures (Hatano et al. 2001, Dias and Rocha 2004, Menezes and Rocha 2011, Menezes et al. 2011), but rarely have they explored the lizard's behavior [e.g., time spent basking (Avery et al. 1982) and rates of exposure to sunlight (Ribeiro and Freire 2010)] before $T_{b}$ was measured. The Brazilian whiptail lizard, Ameivula ocellifera (Spix, 1825) (Squamata: Teiidae) regulates $T_{b}$ with microhabitat temperatures and sunlight in northeastern Brazil (Dias and Rocha 2004, Menezes et al. 2011, Sales and Freire 2016). Owing to this wide distributional range, A. ocellifera is a suitable system in which to investigate intraspecific 
variation in thermal biology with respect to environmental changes. We evaluated the relationships among $\mathrm{T}_{\mathrm{b}}$, microhabitat temperatures, and thermoregulatory behavior in $A$. ocellifera in different seasons (dry and rainy) and populations (two in the semiarid Caatinga and one in Atlantic Forest). Hypothetically, $\mathrm{T}_{\mathrm{b}}$ should be similar in seasons and populations (Huey and Pianka 1977, Kiefer et al. 2007, Menezes and Rocha 2011, Maia-Carneiro and Rocha 2013b) and the thermoregulatory behavior of lizards will likely change to compensate for thermal variations (Kiefer et al. 2007, MaiaCarneiro and Rocha 2013b, Maia-Carneiro et al. 2017).

\section{Materials and Methods}

\section{Study Sites}

Caatinga sites.-The Caatinga comprises a mosaic of deciduous and xerophytic thorny shrubs and seasonally dry forests that extend through most of northeastern Brazil (Velloso et al. 2002, Leal et al. 2005). The two Caatinga study sites are $40 \mathrm{~km}$ apart and located in the municipalities of Lagoa Nova and Acari, state of Rio Grande do Norte, in the Borborema Plateau ecoregion, a mountainous area with rocky granite outcrops (Velloso et al. 2002). This ecoregion is highly degraded and has only small remaining fragments of native vegetation. The climate is warm and semiarid (BShw of Köppen) with rainy season from February-May and an average annual rainfall of 400-650 mm (Velloso et al. 2002).

In Lagoa Nova (hereafter, natural Caatinga), we sampled in a private property known as Serro Alto $\left(06^{\circ} 07^{\prime} 24^{\prime \prime}\right.$ S, 36 33' $31^{\circ}$ ' W; datum: WGS84; $680 \mathrm{~m}$ a.s.l.) in areas with arboreal-shrubby vegetation and sandy soil. This site is located on a mountain ridge and the vegetation is well conserved. Annual means of temperature and mean relative humidity are respectively $27^{\circ} \mathrm{C}$ and $65 \%$ (Beltrão et al. 2005a). In Acari (hereafter: disturbed Caatinga), data were collected on a private property known as Ingá Farm (06 29'07" S, 36 36 36'13" W; datum: WGS84; $299 \mathrm{~m}$ a.s.1.) in areas with shrubby vegetation on banks of an intermittent river (Rio Ingá). The disturbed Caatinga site is located in a mountain valley; the vegetation is disturbed as a result of agriculture and dominated by the pioneer species Mimosa tenuiflora (Willd.) Poir. The annual mean temperature is $27.5^{\circ} \mathrm{C}$ and annual mean relative humidity is 64\% (Beltrão et al. 2005b).

Atlantic Forest site.-The Atlantic Forest is the second largest tropical rainforest in the Americas; its biodiversity is remarkable and the region contains many endemic species of phylogenetically diverse groups (Myers et al. 2000). Originally, it extended along the Brazilian coast from the state of Rio Grande do Norte to the state of Rio Grande do Sul, continuing to the east of Paraguay and northeastern Argentina. However, today the Atlantic Forest is severely fragmented, having lost about $93 \%$ of its vegetation cover (Myers et al. 2000, Tabarelli et al. 2005). The Atlantic Forest is extremely heterogeneous and dominated by tropical pluvial forests that become more seasonal as one moves inland (Tabarelli et al. 2005). Many distinct ecosystems are included in the Atlantic Forest, such as the coastal restingas and the tabuleiros, which are considered isolated cerrado-like savannah areas (Oliveira Filho and Carvalho 1993, Tabarelli et al. 2005).

The Nísia Floresta National Forest (hereafter Atlantic Forest, $06^{\circ} 05^{\prime} 16^{\prime \prime}$ S, 35 $11^{\prime} 07^{\prime \prime} \mathrm{W}$; datum: WGS84; $61 \mathrm{~m}$ a.s.l.) is a protected area (175 ha) located in the municipality of Nísia Floresta, near the coast in the state of Rio Grande do Norte. The climate is warm and humid (sensu Köppen) and the average annual temperature is $26^{\circ} \mathrm{C}$ (Pinto et al. 2012). The rainy season extends from March-July and the dry season from August-February, with annual means of rainfall and relative humidity $1455 \mathrm{~mm}$ and $76 \%$, respectively (Pinto et al. 2012). We studied Ameivula ocellifera in sunny areas along semideciduous forest edges, and shrubby 
vegetation in Tabuleiros areas. The Atlantic Forest study site is located $153 \mathrm{~km}$ and $163 \mathrm{~km}$ from the areas of natural Caatinga and disturbed Caatinga, respectively.

\section{Data Collection and Analytical Procedures}

In the natural Caatinga, we conducted two, 2-wk field excursions-one in the rainy season (03-19 March 2015) and the other in the dry season (17 September-01 October 2015). In the disturbed Caatinga, we conducted one field excursion during the rainy season (09-22 April 2016). We undertook two, 2-wk field excursions in the Atlantic Forest-one in the dry season (03-15 December 2015) and the other in the rainy season (07-16 June 2016).

We recorded thermoregulatory behavior in Ameivula ocellifera on sunny or partially cloudy days during the lizard's daily activity period from 09:00-16:00 h (Vitt 1995, Dias and Rocha 2004) with a digital camcorder (Sony HDR-CX190). To locate lizards in the field, one of us (RFDS) walked slowly through areas of shrubby-herbaceous vegetation and edges of arboreal areas, habitats in which A. ocellifera occurs in great abundance (pers. observ.). When a lizard was detected, the observer stopped moving immediately and waited about 2 min to ensure that the lizard had not been disturbed; standing at least $3 \mathrm{~m}$ away (Cooper Jr. 2005), the observer remained immobile, moving only if the vegetation obstructed the view or the lizard was considerably more than $3 \mathrm{~m}$ away. At the hint of any disturbance to the lizard, observation ceased; the minimum time was 5 min, but most observations lasted between 10 and $13 \mathrm{~min}$.

After observing a lizard, it was shot with a pellet rifle $(4.5 \mathrm{~mm})$ and its cloacal temperatures measured within $30 \mathrm{~s}$ with a temperature sensor (Instrutherm ${ }^{\circledR}$ model S- $02 \mathrm{~K}$ ) coupled to a digital thermohygrometer (precision of $0.1^{\circ} \mathrm{C}$; Instrutherm $^{\circledR}$ model HTR-350). Lizards were held by their limbs to minimize heat conduction from the researcher to the animal (Brattstrom,
1965). The capture and killing of the lizards were approved by the Committee on Ethics in the Use of Animals of the Universidade Federal do Rio Grande do Norte, CEUA/UFRN (Protocol No. 32/2015), and authorized by the Biodiversity Information and Authorization System of Chico Mendes Institute for Biodiversity Conservation (SISBIO-ICMBio, Authorization No. 47922). We recorded substrate $\left(\mathrm{T}_{\mathrm{s}}\right)$ and air temperatures $\left(\mathrm{T}_{\mathrm{a}}\right) 1 \mathrm{~cm}$ above the substrate by positioning the measuring devices at the site from which the lizard was at the end of focal observation. The snout-vent length (SVL) and sex of each lizard was recorded. The specimens were fixed in $10 \%$ formaldehyde and preserved in $70 \%$ ethanol, and deposited in the Herpetological Collection of Rio Grande do Norte Federal University (voucher numbers: UFRN 4894-4914, 5119-5135, 52815320). In natural Caatinga and Atlantic Forest, we collected additional lizards that were not observed to increase sample sizes and thus enhance reliability of analyses involving $\mathrm{T}_{\mathrm{s}}, \mathrm{T}_{\mathrm{a}}$, and $\mathrm{T}_{\mathrm{b}}$.

We analyzed the videos using continuous focal animal sampling (Martin and Bateson 2007): the true frequency and duration of each behavior were measured, as well as the times at which behavior patterns stopped and started. The four behavioral categories were: (1) foraging; (2) vigilance; (3) basking; and (4) social interactions (Appendix I). Thermoregulatory behavior was evaluated by recording the lizard's: (1) body postures while basking and the duration of these episodes in relation to the total observation time; and (2) behavior when exposed to sunlight. We assumed that the lizards thermoregulated constantly, even when performing other activities, such as foraging [refer to Huey and Slatkin (1976) and Rocha et al. (2009) for the rationale of why we evaluated sunlight exposure behavior during the entire observation period]. Sunlight exposure classes were adapted from Ribeiro and Freire (2010) as percentage of time exposed to: (1) sunlight; (2) filtered sunlight (a mosaic of sun and shade under vegetation); (3) shade; and (4) cloudy conditions (Appendix II). 
We estimated mean body $\left(\mathrm{T}_{\mathrm{b}}\right)$, substrate $\left(\mathrm{T}_{\mathrm{s}}\right)$, and air $\left(\mathrm{T}_{\mathrm{a}}\right)$ temperatures for each season and population by calculating arithmetic means of body, substrate, and air temperatures. Levels of thermoregulation $(\Delta \mathrm{T})$ in each season and population were calculated by obtaining the difference between $\mathrm{T}_{\mathrm{b}}$ and $\mathrm{T}_{\mathrm{s}}\left(\Delta \mathrm{T}_{\mathrm{s}}=\mathrm{T}_{\mathrm{b}}-\mathrm{T}_{\mathrm{s}}\right)$ and between $\mathrm{T}_{\mathrm{b}}$ and $\mathrm{T}_{\mathrm{a}}\left(\Delta \mathrm{T}_{\mathrm{a}}=\mathrm{T}_{\mathrm{b}}-\mathrm{T}_{\mathrm{a}}\right)$ following the methods of Vrcibradic and Rocha (1998), Kiefer et al. (2007), Sousa and Freire (2011), and MaiaCarneiro and Rocha (2013b). The higher the absolute values of $\Delta \mathrm{T}_{\mathrm{s}}$ and $\Delta \mathrm{T}_{\mathrm{a}}$, the higher the degree of active thermoregulation in relation to microhabitat temperatures (Kiefer et al. 2007). The effects from microhabitat temperatures $\left(\mathrm{T}_{\mathrm{s}}\right.$ and $\mathrm{T}_{\mathrm{a}}$ ) on body temperatures were estimated by simple linear regression analyses. Differences in $\mathrm{T}_{\mathrm{b}}, \mathrm{T}_{\mathrm{s}}, \mathrm{T}_{\mathrm{a}}, \Delta \mathrm{T}_{\mathrm{s}}, \Delta \mathrm{T}_{\mathrm{a}}$ between dry and rainy seasons and the percentages of time spent in each class of sunlight exposure were calculated by independent t-tests or Mann-Whitney $\mathrm{U}$ tests, depending of data distributions. Differences among populations with respect to the foregoing variables were evaluated by analysis of variance (ANOVA) with Tukey post-hoc tests for pairwise comparisons, or Mann-Whitney $U$ tests if variables did not have normal distributions. We used Spearman's correlation analysis to test for relationships between percentage of time spent basking and percentage of time exposed to cloudy conditions, and between percentage of time spent basking and $\mathrm{T}_{\mathrm{b}}$. All statistical analyses were performed using SPSS Statistics 20.0 (IBM) software for Windows $(\alpha=0.05)$. All variables were tested for normality and homoscedasticity of variances before performing parametric tests. We report descriptive statistics as means $\pm \mathrm{SD}$.

\section{Results}

Data on thermoregulatory behaviors of 63 Ameivula ocellifera were gathered at three study sites for a total of $755.1 \mathrm{~min}$ or $12.6 \mathrm{~h}$ of observation. Thirty recordings were made in natural Caatinga -18 in the rainy season and 12 in the dry season. Two lizards were collected without being observed in natural Caatinga, one in each season, to enhance sampling of $T_{b}, T_{s}$ and $\mathrm{T}_{\mathrm{a}}$ measured in the field; thus, the total number of lizards collected was 32 (16 males, 12 females, 4 juveniles). Twenty recordings were made in the disturbed Caatinga in the rainy season when we measured $\mathrm{T}_{\mathrm{b}}, \mathrm{T}_{\mathrm{s}}$ and $\mathrm{T}_{\mathrm{a}}$ for each individual (9 males, 11 females). Thirteen recordings were made in the Atlantic Forest (10 in the rainy season and 3 in the dry season) and six lizards were collected without being observed ( 2 in the rainy season and 4 in the dry season) to complete sampling of $\mathrm{T}_{\mathrm{b}}, \mathrm{T}_{\mathrm{s}}$ and $\mathrm{T}_{\mathrm{a}}$ measured in the field (11 males, 8 females, 1 juvenile). Mean values of all thermal variables are shown in Table 1. We found no influence of sex and age on $\mathrm{T}_{\mathrm{b}}$ in any of the three populations (ANOVA, natural Caatinga: $F_{2,29}=0.949, p=0.399$; disturbed Caatinga: $\stackrel{\mathrm{F}}{1,18}=0.732, p=0.403$; Atlantic Forest: $F_{2,17}=1.381, p=0.278$ ); therefore, we performed all analyses with males, females and juveniles pooled in each population/ season.

Ameivula ocellifera at all three sites spent most of their time foraging by searching by visual and chemosensory means (i.e., tongueflicking air and substrate while standing or moving) and digging or turning over the substrate in their search for prey. The lizards often stop active searching and maintain a vigilant stance for varying amounts of time, before resuming foraging. While moving, lizards often switch between areas with direct sunlight, filtered sunlight, and shade. Sometimes, lizards stop foraging to bask, which is a behavior strictly related to thermoregulation. Basking lizards remain motionless with their heads propped on the substrate or slightly inclined, and the foreand hind limbs resting with their toes in contact with the ground or raised, so that the lizard rests on its wrists and ankles (Appendices I, III). Some basking animals often blink slowly, lethargically, but this behavior did not occur in all basking episodes. Another common behavior was opening the mouth wide, similar to a yawn. 
Table 1. Average values (ranges in parentheses) of body $\left(\mathrm{T}_{\mathrm{b}}\right)$, substrate $\left(\mathrm{T}_{\mathrm{s}}\right)$, and air $\left(\mathrm{T}_{\mathrm{a}}\right)$ temperatures in ${ }^{\circ} \mathrm{C}$, and $\Delta \mathrm{T}_{\mathrm{s}}$ and $\Delta \mathrm{T}_{\mathrm{a}}$ of three populations of Ameivula ocellifera in the state of Rio Grande do Norte, northeastern Brazil.

\begin{tabular}{|c|c|c|c|c|c|c|c|}
\hline \multirow{2}{*}{$\begin{array}{l}\text { Varia- } \\
\text { bles }\end{array}$} & \multicolumn{3}{|c|}{ Natural Caatinga } & \multirow{2}{*}{$\begin{array}{c}\begin{array}{c}\text { Disturbed } \\
\text { Caatinga }\end{array} \\
\begin{array}{c}\text { Rainy season } \\
(N=20)\end{array}\end{array}$} & \multicolumn{3}{|c|}{ Atlantic Forest } \\
\hline & $\begin{array}{l}\text { Rainy season } \\
\qquad(N=19)\end{array}$ & $\begin{array}{l}\text { Dry season } \\
\qquad(N=13)\end{array}$ & $\begin{array}{l}\text { Both seasons } \\
\qquad(N=32)\end{array}$ & & $\begin{array}{l}\text { Rainy season } \\
\qquad(N=13)\end{array}$ & $\begin{array}{l}\text { Dry season } \\
\qquad(N=7)\end{array}$ & $\begin{array}{l}\text { Both seasons } \\
\quad(N=20)\end{array}$ \\
\hline $\mathrm{T}_{\mathrm{b}}$ & $\begin{array}{c}38.5 \pm 2.6 \\
(33.3-41.5)\end{array}$ & $\begin{array}{c}38.2 \pm 3.7 \\
(32.4-43.2)\end{array}$ & $\begin{array}{c}38.4 \pm 3.0 \\
(32.4-43.2)\end{array}$ & $\begin{array}{c}38.0 \pm 2.0 \\
(33.2-41.2)\end{array}$ & $\begin{array}{c}38.9 \pm 1.4 \\
(36.7-41.9)\end{array}$ & $\begin{array}{c}40.1 \pm 3.0 \\
(36.6-43.4)\end{array}$ & $\begin{array}{c}39.3 \pm 2.1 \\
(36.6-43.4)\end{array}$ \\
\hline $\mathrm{T}_{\mathrm{s}}$ & $\begin{array}{c}32.1 \pm 3.0 \\
(28.1-38.7)\end{array}$ & $\begin{array}{c}36.4 \pm 5.0 \\
(26.4-43.5)\end{array}$ & $\begin{array}{c}33.9 \pm 4.4 \\
(26.4-43.5)\end{array}$ & $\begin{array}{c}34.6 \pm 3.0 \\
(27.9-39.5)\end{array}$ & $\begin{array}{c}34.6 \pm 3.3 \\
(29.2-40.5)\end{array}$ & $\begin{array}{c}39.7 \pm 5.6 \\
(35.0-48.1)\end{array}$ & $\begin{array}{c}36.4 \pm 4.8 \\
(29.2-48.1)\end{array}$ \\
\hline $\mathrm{T}_{\mathrm{a}}$ & $\begin{array}{c}31.0 \pm 3.0 \\
(26.4-36.3)\end{array}$ & $\begin{array}{c}32.8 \pm 1.4 \\
(30.1-34.9)\end{array}$ & $\begin{array}{c}31.7 \pm 2.6 \\
(26.4-36.2)\end{array}$ & $\begin{array}{c}32.1 \pm 2.4 \\
(27.0-35.8)\end{array}$ & $\begin{array}{c}33.6 \pm 2.4 \\
(29.9-33.6)\end{array}$ & $\begin{array}{c}35.0 \pm 1.7 \\
(33.1-36.9)\end{array}$ & $\begin{array}{c}34.1 \pm 2.2 \\
(29.9-36.9)\end{array}$ \\
\hline$\Delta \mathrm{T}_{\mathrm{s}}$ & $\begin{array}{c}6.4 \pm 2.1 \\
(2.7-10.5)\end{array}$ & $\begin{array}{l}2.8 \pm 2.0 \\
(0.7-6.0)\end{array}$ & $\begin{array}{c}4.9 \pm 2.7 \\
(0.7-10.5)\end{array}$ & $\begin{array}{l}3.7 \pm 2.4 \\
(0.2-8.8)\end{array}$ & $\begin{array}{c}4.3 \pm 2.8 \\
(1.4-11.0)\end{array}$ & $\begin{array}{l}4.0 \pm 2.7 \\
(0.1-6.9)\end{array}$ & $\begin{array}{c}4.2 \pm 2.7 \\
(0.1-11.0)\end{array}$ \\
\hline$\Delta \mathrm{T}_{\mathrm{a}}$ & $\begin{array}{c}7.5 \pm 2.6 \\
(2.7-10.7)\end{array}$ & $\begin{array}{l}5.4 \pm 3.1 \\
(0.5-9.1)\end{array}$ & $\begin{array}{c}6.6 \pm 2.9 \\
(0.5-10.7)\end{array}$ & $\begin{array}{l}5.9 \pm 2.4 \\
(0.1-9.7)\end{array}$ & $\begin{array}{c}5.3 \pm 2.2 \\
(2.5-10.3)\end{array}$ & $\begin{array}{l}5.2 \pm 3.0 \\
(0.3-8.7)\end{array}$ & $\begin{array}{c}5.3 \pm 2.4 \\
(0.3-10.3)\end{array}$ \\
\hline
\end{tabular}

Basking episodes are less frequent than foraging and vigilance, but were recorded during most observations. Social interactions, including agonistic encounters and reproductive behavior, were rarely recorded.

\section{Seasonal Comparisons Within Populations}

In natural Caatinga, $\mathrm{T}_{\mathrm{b}}$ did not differ between dry and rainy seasons $(\mathrm{t}=0.220, d f=30, p=$ $0.827)$, but $\mathrm{T}_{\mathrm{s}}(\mathrm{t}=-2.788, d f=17.838, p=0.012)$ and $\mathrm{T}_{\mathrm{a}}(\mathrm{t}=-2.250, d f=26.758, p=0.033)$ were higher in the dry season (Figure 1). In the rainy season, $\mathrm{T}_{\mathrm{b}}$ was significantly higher than microhabitat temperatures $\left(\mathrm{T}_{\mathrm{s}}: \mathrm{t}=7.012, d f=\right.$ $36, p<0.001 ; \mathrm{T}_{\mathrm{a}}: \mathrm{t}=8.205, d f=36, p<0.001$; Figure 1); in the dry season $\mathrm{T}_{\mathrm{b}}$ was significantly higher than $\mathrm{T}_{\mathrm{a}}(\mathrm{t}=5.002, d f=15.2, p<0.001)$, but did not differ from $\mathrm{T}_{\mathrm{s}}(\mathrm{t}=1.028, d f=24, p=$ 0.314 ; Figure 1$). \Delta \mathrm{T}_{\mathrm{s}}$ was higher during the rainy season $(\mathrm{t}=4.865, d f=30, p<0,001$, Figure 2$)$ and $\Delta \mathrm{T}_{\mathrm{a}}$ was approximately $28 \%$ higher also in rainy season at a level of significance $0.057(\mathrm{t}=$ 1.983, $d f=30, p=0.057$, Figure 2). Lizards spent more time exposed to sun in the rainy season than in the dry season (Mann-Whitney, $\mathrm{U}$ $=43.0, p=0.006$, Figure $3 \mathrm{~A}$ ) and more time exposed to filtered sun during the dry season than in the rainy season (Mann-Whitney, $\mathrm{U}=$ 43.0, $p=0.006$, Figure 3B). There were no seasonal differences of time in shade (MannWhitney, $\mathrm{U}=107.5, p=0.983$, Figure 3C), time exposed to cloudy conditions (Mann-Whitney, U $=91.0, p=0.457$; Figure 3D), and time spent basking (Mann-Whitney, $\mathrm{U}=78.0, p=0.130$; Figure 4).

In the Atlantic Forest, none of the temperature variables changed seasonally $\left(\mathrm{T}_{\mathrm{b}}: \mathrm{t}=1.064, d f=\right.$ $7.55, p=0.320 ; \mathrm{T}_{\mathrm{a}}: \mathrm{t}=1.377, d f=18, p=0.185 ;$ Figure $1 ; \Delta \mathrm{T}_{\mathrm{s}}: \mathrm{t}=-0.196, d f=18, p=0.847$; $\Delta \mathrm{T}_{\mathrm{a}}: \mathrm{t}=-0.042, d f=18, p=0.967$; Figure 2), but $\mathrm{T}_{\mathrm{s}}$ was around $13 \%$ higher during the dry season at a significance level of $0.055(\mathrm{t}=2.237$, $d f=8.272, p=0.055)$. There were no seasonal differences in time exposed to sunlight classes (Mann-Whitney, time exposed to sun: $\mathrm{U}=14.5$, $p=0.932$; time exposed to filtered sun: $\mathrm{U}=4.0$, $p=0.063$; time in shade: $\mathrm{U}=11.0, p=0.497$; time exposed to cloudy conditions: $\mathrm{U}=14.0, p$ $=0.836) . \mathrm{T}_{\mathrm{b}}$ was significantly higher than microhabitat temperatures in the rainy season $\left(\mathrm{T}_{\mathrm{s}}: \mathrm{t}=3.978, d f=9.6, p=0.003 ; \mathrm{T}_{\mathrm{a}}: \mathrm{t}=4.312\right.$, $d f=16.5, p=0.001$; Figure 1); in the dry season $\mathrm{T}_{\mathrm{b}}$ was significantly higher than $\mathrm{T}_{\mathrm{a}}(\mathrm{t}=3.978$, 


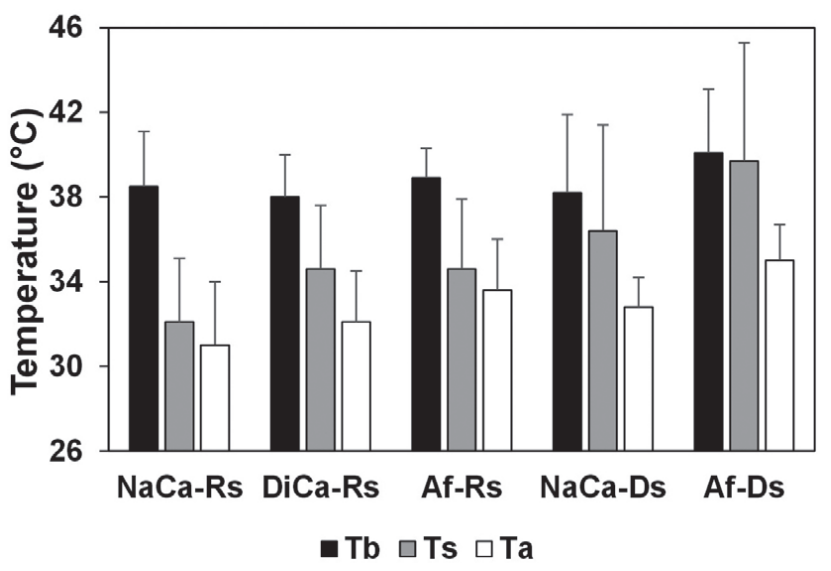

Figure 1. Means of body temperatures $\left(T_{b}\right)$, of substrate temperatures $\left(\mathrm{T}_{\mathrm{s}}\right)$ and of air temperatures $\left(\mathrm{T}_{\mathrm{a}}\right)$ in three populations of Ameivula ocellifera in the state of Rio Grande do Norte, northeastern Brazil. Error bars indicate \pm 1 standard deviation. Abbreviations: NaCa-Rs, natural Caatinga in the rainy season; DiCa-Rs, disturbed Caatinga in the rainy season; Af-Rs, Atlantic Forest in the rainy season; $\mathrm{NaCa}-\mathrm{Ds}$, natural Caatinga in the dry season; and Af-Ds, Atlantic Forest in the dry season.

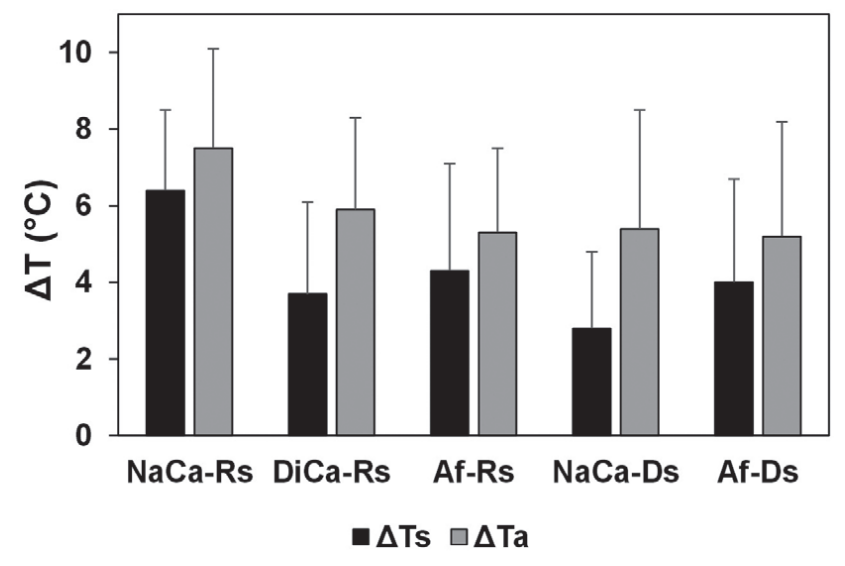

Figure 2. Means of absolute differences between mean body temperatures and mean substrate temperatures $\left(\Delta \mathrm{T}_{\mathrm{s}}\right)$ and between mean body temperatures and mean air temperatures $\left(\Delta \mathrm{T}_{\mathrm{a}}\right)$ in three populations of Ameivula ocellifera in the state of Rio Grande do Norte, northeastern Brazil. Error bars indicate \pm 1 standard deviation (SD). Abbreviations: NaCa-Rs, natural Caatinga in the rainy season; DiCa-Rs, disturbed Caatinga in the rainy season; Af-Rs, Atlantic Forest in the rainy season; NaCa-Ds, natural Caatinga in the dry season; and Af-Ds, Atlantic Forest in the dry season.

the dry season, $\mathrm{T}_{\mathrm{b}}(\mathrm{t}=-1.189, d f=18, p=0.250)$ and $\mathrm{T}_{\mathrm{s}}(\mathrm{t}=-1.351, d f=18, p=0.193)$ were similar in the natural Caatinga and the Atlantic Forest, but $\mathrm{T}_{\mathrm{a}}$ differed between these sites $(\mathrm{t}=-3.167, d f=18, p=0.005$; Figure 1).

In natural Caatinga, there are positive relationships between $\mathrm{T}_{\mathrm{b}}$ and $\mathrm{T}_{\mathrm{s}}\left(\mathrm{r}^{2}=0.433\right.$, $\left.F_{1,30}=22.911, p<0.001\right)$ and between $\mathrm{T}_{\mathrm{b}}$ and $\mathrm{T}_{\mathrm{a}}$ $\left(\mathrm{r}^{2}=0.209, F_{1,30}=7.938, p<0.001\right)$. In disturbed Caatinga, $\mathrm{T}_{b}$ was not related to $\mathrm{T}_{\mathrm{a}}\left(\mathrm{r}^{2}=0.155\right.$, $\left.F_{1,18}=3.295, p=0.086\right)$, but associated marginally with $\mathrm{T}_{\mathrm{s}}$ at a level of significance of $0.056\left(\mathrm{r}^{2}=0.188, F_{1,18}=4.162, p=0.056\right)$. In the Atlantic Forest, $\mathrm{T}_{\mathrm{b}}$ had positive relationship with $\mathrm{T}_{\mathrm{s}}\left(\mathrm{r}^{2}=0.277, F_{1,18}=6.897, p=0.017\right)$, but not with $\mathrm{T}_{\mathrm{a}}\left(\mathrm{r}^{2}=0.113, F_{1,18}=2.289, p=0.148\right)$.

Values of $\Delta \mathrm{T}_{\mathrm{s}}\left(\mathrm{F}_{2,49}=6.368, p=0.003\right)$ and $\Delta \mathrm{T}_{\mathrm{a}}\left(\mathrm{F}_{2,49}=3.464, p=0.039\right)$ differed among populations in the rainy season. Differences in 

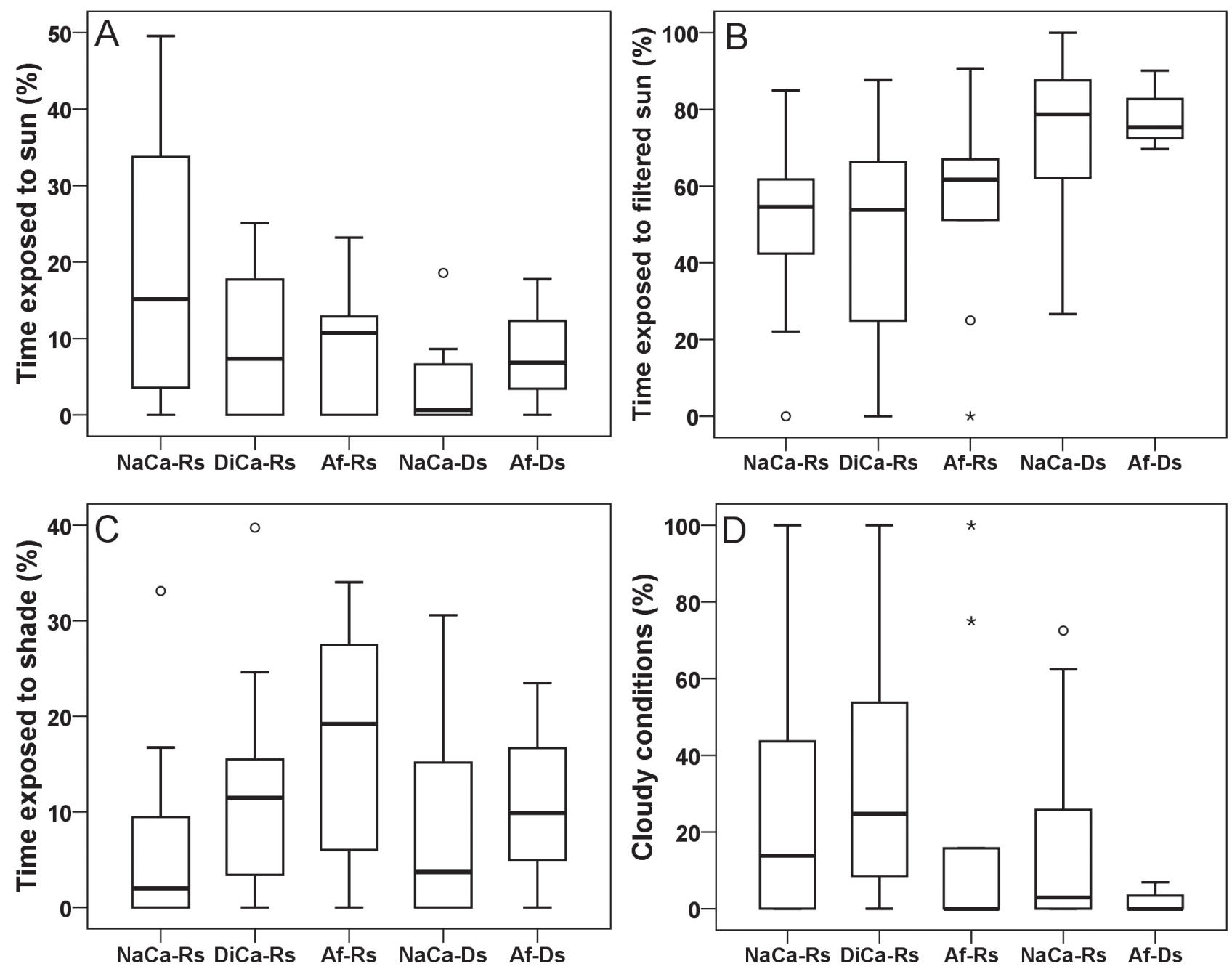

Figure 3. Percentages of time Ameivula ocellifera exposed to sunlight categories in three populations in the state of Rio Grande do Norte, northeastern Brazil. A: exposed to sun; B: exposed to filtered sun; C: exposed to shade; D: exposed to cloudy conditions. Abbreviations: NaCa-Rs, natural Caatinga in the rainy season; DiCa-Rs, disturbed Caatinga in the rainy season; Af-Rs, Atlantic Forest in the rainy season; NaCa-Ds, natural Caatinga in the dry season; and Af-Ds, Atlantic Forest in the dry season.

$\Delta \mathrm{T}_{\mathrm{s}}$ occurred between the two Caatinga populations (post-hoc Tukey, $p=0.004$ ) and between natural Caatinga and Atlantic Forest (post-hoc Tukey, $p=0.045$; Figure 2). The difference in $\Delta \mathrm{T}_{\mathrm{a}}$ occurred between natural Caatinga and Atlantic Forest (post-hoc Tukey, $p$ $=0.045$; Figure 2). In the dry season, natural Caatinga and Atlantic Forest populations did not differ in $\Delta \mathrm{T}_{\mathrm{s}}(\mathrm{t}=-1.155, d f=18, p=0.263)$ and in $\Delta \mathrm{T}_{\mathrm{a}}(\mathrm{t}=0.135, d f=18, p=0.894)$. Pooling all three populations, most values of $\Delta \mathrm{T}_{\mathrm{s}}(88.9 \%)$ and $\Delta \mathrm{T}_{\mathrm{a}}(98.6 \%)$ were positive, indicating that $\mathrm{T}_{\mathrm{b}}$ tended to be higher than both $\mathrm{T}_{\mathrm{s}}$ and $\mathrm{T}_{\mathrm{a}}$. Some negative values of $\Delta \mathrm{T}_{\mathrm{s}}$ were registered in the dry season in conserved Caatinga $(N=3)$, in the rainy season in disturbed Caatinga $(N=2)$, and in the dry season in the Atlantic Forest $(N=3)$. Negative values of $\Delta \mathrm{T}_{\mathrm{a}}$ were recorded only in the dry season in the Atlantic Forest $(N=1)$.

Lizards from all populations spent most of 


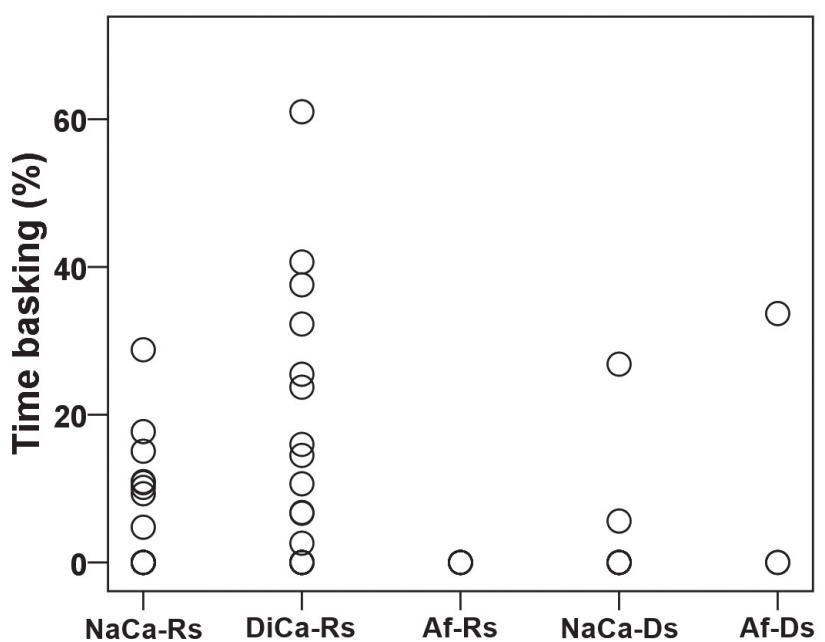

Figure 4. Percentages of time spent basking of Ameivula ocellifera in three populations in the state of Rio Grande do Norte, northeastern Brazil. Abbreviations: NaCa-Rs, natural Caatinga in the rainy season; DiCa-Rs, disturbed Caatinga in the rainy season; Af-Rs, Atlantic Forest in the rainy season; $\mathrm{NaCa}-\mathrm{Ds}$, natural Caatinga in the dry season; and Af-Ds, Atlantic Forest in the dry season.

their time exposed to filtered sun (Table 2, Figure $3 \mathrm{~B})$. In the rainy season, time exposed to filtered sun did not differ among populations $\left(F_{2,45}=0.407, p=0.668\right.$; Figure 3B $)$, but lizards from natural Caatinga spent more time exposed to sun than lizards from disturbed Caatinga (Mann-Whitney, $\mathrm{U}=109.0, p=0.036$; Figure $3 \mathrm{~A})$ and less time in the shade than lizards from the Atlantic Forest (Mann-Whitney, $\mathrm{U}=49.0, p$ $=0.048$; Figure $3 \mathrm{C}$ ). In the rainy season, there is a difference (Figure 3D) in the time lizards spent exposed to cloudy conditions in disturbed Caatinga and in the Atlantic Forest (MannWhitney, $\mathrm{U}=55.0, p=0.044$; Figure 3D).

Interpopulation comparisons of Ameivula ocellifera in the dry season were only made at the natural Caatinga and the Atlantic Forest. There were no differences between these two populations in time exposed to sunlight classes (Mann-Whitney, time exposed to sun: $U=13.5$, $p=0.502$; time exposed to filtered sun: $\mathrm{U}=15.0, p=0.665$; time in shade: $\mathrm{U}=14.5, p$

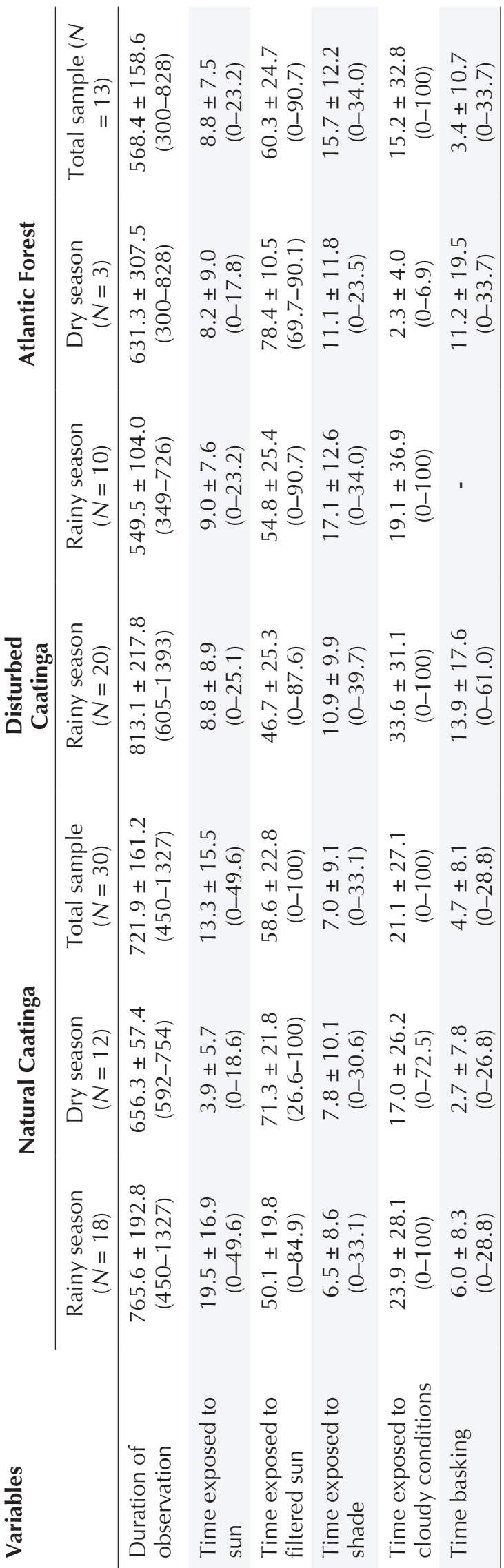


$=0.497$; time exposed to cloudy conditions: $\mathrm{U}=13.0, p=0.434$ ).

Time spent basking differed between disturbed Caatinga and the other two populations (Mann-Whitney, disturbed Caatinga $\times$ natural Caatinga: $\mathrm{U}=203.0, p=0.034$; disturbed Caatinga $\times$ Atlantic Forest: $\mathrm{U}=53.0, p=0.039$; Figure 4), but not between natural Caatinga and the Atlantic Forest $(\mathrm{U}=120.0, p=0.234)$. When populations are pooled, time spent basking has a positive correlation with time exposed to cloudy conditions $\left(\mathrm{r}_{\mathrm{s}}=0.420, p<0.001, N=79\right)$, and negatively with $\mathrm{T}_{\mathrm{b}}\left(\mathrm{r}_{\mathrm{s}}=-0.369, p=0.004\right.$, $N=60)$.

\section{Discussion}

Some of the highest activity body temperatures occur in teiid lizards (Vitt and Pianka 2004). The prevalence of high body temperatures in teiids suggests this feature, which has both physiological and behavioral components, is conservative, having emerged early in the evolutionary history of the family (Vitt et al. 1997, Menezes and Rocha 2011). Mean body temperatures of South American whiptail lizards, including Ameivula, Cnemidophorus, Contomastix, and Glaucomastix, range from $36-41{ }^{\circ} \mathrm{C}$ (Vitt et al. 1997, Mesquita and Colli 2003, Vitt et al. 2005, Menezes and Rocha 2011). Mean body temperatures of the populations of $A$. ocellifera in this study range from $38-39^{\circ} \mathrm{C}$, which is consistent with data for other whiptail species, as well as medium-sized teiids, such as Ameiva ameiva (Linnaeus, 1758) (Morgan 1988, Sales et al. 2011). The uniformity of $\mathrm{T}_{\mathrm{b}}$ among our populations suggests that body temperatures in lizards may reflect phylogeny more than ecology (Bogert 1949, Schall 1977, Andrews 1998). Similar results were found in other comparative studies of South American (Menezes and Rocha 2011, Albuquerque et al. 2018) and North American whiptails (Schall 1977).

Body temperatures of active lizards reflect interactions with different environmental thermal sources, such as sunlight, and substrate and air temperatures (Bogert 1949, Brattstrom 1965; Huey and Slatkin 1976, Rocha et al. 2009). Substrate and air temperatures were lower in natural Caatinga than in disturbed Caatinga and the Atlantic Forest, and these temperatures varied seasonally in natural Caatinga, being milder in the rainy season; nevertheless, among the populations we investigated, the body temperatures of the lizards were the same. Additionally, $\mathrm{T}_{\mathrm{b}}$ was higher than microhabitat temperatures in the rainy season in all three populations, but the same as the $\mathrm{T}_{\mathrm{s}}$ in the dry season. Seasonal and populational differences of $\Delta \mathrm{T}_{\mathrm{s}}$ and $\Delta \mathrm{T}_{\mathrm{a}}$ reflect variation in microhabitat temperatures. Taken together, our results indicate that Ameivula ocellifera: (1) uses environmental thermal sources (e.g., solar radiation) other than microhabitat temperatures to regulate body temperatures; and/or (2) the lizards have efficient physiological mechanisms to conserve heat regardless of variation in external temperatures. The thermoregulatory behaviors we observed support the first hypothesis.

Lizards mainly regulate body temperatures behaviorally by moving between direct sunlight, filtered sun, and shaded sites to control heat exchange with the environment (Cowles and Bogert 1944, Bogert 1949, Rocha et al. 2009), thereby maintaining a more or less constant body temperature in changing thermal environments (Vitt et al. 2005, Menezes and Rocha 2011, Albuquerque et al. 2018, this study). For example, in natural Caatinga, A. ocellifera spent more time in the sun and less time in the shade than lizards in the other two populations. Moreover, lizards spent more time in the sun and less time exposed to filtered sunlight in the cooler season; this seems to account for the higher $\Delta \mathrm{T}_{\mathrm{s}}$ and $\Delta \mathrm{T}_{\mathrm{a}}$ in the rainy season and the absence of seasonal differences of $T_{b}$ in this population. Likewise, analyses of $\Delta \mathrm{T}_{\mathrm{s}}$ and $\Delta \mathrm{T}_{\mathrm{a}}$ suggest that Brazilian sand lizards (Liolaemus lutzae Mertens, 1938) in Rio de Janeiro adjust their thermoregulatory behavior seasonally (Maia-Carneiro and Rocha 2013b). Analyses of 
rates of exposure to sunlight by tropidurid lizards, Tropidurus hispidus (Spix, 1825) and T. semitaeniatus (Spix, 1825), in the Caatinga of northeastern Brazil revealed seasonal variations in thermoregulatory behavior (Ribeiro and Freire 2010).

Behavioral postures exhibited by A. ocellifera during basking resemble the "prostrate posture" and "prostrate posture with a slight inclination of the head" reported for an Amazon population of the teiid Ameiva ameiva (Cruz-Neto and Gordo 1996). By changing body postures and bringing the entire ventral surface of the body in contact with the substrate, lizards control heat exchange by conduction (Heatwole and Taylor 1987, Belliure and Carrascal 2002). This would explain why lizards in disturbed Caatinga spent more time basking in this posture than did lizards in the other two populations (Figure 4), which experienced longer periods of partly sunny exposure (Figure 3). This is consistent with our observation that $A$. ocellifera exposed to cloudy conditions for longer periods spent more time basking. Likewise, lacertid lizards Zootoca (= Lacerta) vivipara (Lichtenstein, 1823) spent more time basking when subject to simulated decrease in solar radiation (Avery et al. 1982). Clouds decrease the incidence of sunlight on the ground, and thus restrict heat gain by lizards; the animals are forced to stop moving and assume one of several body postures to bask and conduct heat from the substrate to the body.

The ability to move among sites with different levels of sunlight is an important mechanism for A. ocellifera to conserve its $\mathrm{T}_{\mathrm{b}}$ in the face of seasonal thermal changes and thermal differences in populations. Low correlations or absence of a relationship of $\mathrm{T}_{\mathrm{b}}$ with $\mathrm{T}_{\mathrm{s}}$ and $\mathrm{T}_{\mathrm{a}}$ in the three study populations suggest that these lizards use sunlight to increase body temperatures. We were able to evaluate the contribution of solar radiation to thermoregulation under varying thermal conditions in A. ocellifera by measuring time spent basking and exposure to sunlight classes. Variation in body temperatures of five species of whiptails (including A. ocellifera) in sand dunes of northeastern and southeastern Brazilian coast were explained by differences in substrate and air temperatures; however, other unidentified sources (such as sunlight) were thought to have increased the body temperatures of the lizards above ambient temperatures (Menezes and Rocha 2011). Other relevant factors involved in heat gain and loss by lizards, such as intensity of winds (Maia-Carneiro et al. 2012, 2017), may have contributed to variations of body temperatures of A. ocellifera; the latter remains to be determined. Nevertheless, body temperature regulation in these lizards is favored by exposure to warming radiation from the sun.

\section{Acknowledgments}

This study was supported by research grants from Coordernação de Aperfeiçoamento de Pessoal de Nível Superior (CAPES) to RFDS (process 1558610) and from Conselho Nacional de Desenvolvimento Científico e Tecnológico (CNPq) to EMXF (process 313661/2017-0). We are grateful to the anonymous reviewers who provided valuable comments.

\section{References}

Albuquerque, R. L., A. S. Protázio, L. B. Q. Cavalcanti, L. C. S. Lopez, and D. O. Mesquita. 2018. Geographical ecology of Tropidurus hispidus (Squamata: Tropiduridae) and Cnemidophorus ocellifer (Squamata: Teiidae) in Neotropical region: a comparison among Atlantic Forest, Caatinga and coastal populations. Journal of Herpetology 52: 145-155.

Andrews, R. M. 1998. Geographic variation in field body temperature of Sceloporus lizards. Journal of Thermal Biology 23: 329-334.

Avery, R. A., J. D. Bedford, and C. P. Newcombe. 1982. The role of thermoregulation in lizard biology: predatory efficiency in a temperate diurnal basker. Behavioral Ecology and Sociobiology 11: 261-267.

Bauwens, D., P. E. Hertz, and A. M. Castilla. 1996. Themoregulation in a lacertid lizard: the relative contributions of distinct behavioral mechanisms. Ecology 77: 1818-1830. 
Belliure, J. and L. M. Carrascal. 2002. Influence of heat transmission mode on heating rates and on the selection of patches for heating in a Mediterranean lizard. Physiological and Biochemical Zoology 75: 369-376.

Beltrão, B. A., D. E. G. A. Rocha, J. C. Mascarenhas, L. C. Souza Junior, S. T. M. Pires, and V. G. D. Carvalho. 2005a. Projeto Cadastro de Fontes de Abastecimento por Água Subterrânea, Diagnóstico do Município de Lagoa Nova, Estado do Rio Grande do Norte. Recife. CPRM / PRODEEM. $11 \mathrm{pp}$.

Beltrão, B. A., D. E. G. A. Rocha, J. C. Mascarenhas, L. C. Souza Junior, S. T. M. Pires, and V. G. D. Carvalho. 2005b. Projeto Cadastro de Fontes de Abastecimento por Água Subterrânea, Diagnóstico do Município de Acari, Estado do Rio Grande do Norte. Recife. CPRM / PRODEEM. $11 \mathrm{pp}$.

Bogert, C. M. 1949. Thermoregulation in reptiles: a factor in evolution. Evolution 3: 195-211.

Brattstrom, B. H. 1965. Body temperatures of reptiles. American Midland Naturalist 73: 376-422.

Cooper Jr., W. E. 2005. Lizard foraging modes: global need for data, methods for data collection and call for data. Herpetological Review 36: 367-369.

Cowles, R. B. and C. M. Bogert. 1944. A preliminary study of the thermal requirements of desert reptiles. Bulletin of the American Museum of Natural History 83: 265-296.

Cruz-Neto, A. P. and M. Gordo. 1996. Body temperature and thermoregulatory behavior of the lizard Ameiva ameiva in central Amazonian forests. Studies on Neotropical Fauna and Environment 31: 11-16.

Dias, E. J. R. and C. F. D. Rocha. 2004. Thermal ecology, activity patterns, and microhabitat use by two sympatric whiptail lizards (Cnemidophorus abaetensis and Cnemidophorus ocellifer) from Northeastern Brazil. Journal of Herpetology 38: 586-588.

Hatano, F. H., D. Vrcibradic, C. A. B. Galdino, M. CunhaBarros, C. F. D. Rocha, and M. Van Sluys. 2001. Thermal ecology and activity patterns of the lizard community of the restinga of Jurubatiba, Macaé, RJ. Revista Brasileira de Biologia 61: 287-294.

Heatwole, H. and J. Taylor. 1987. Ecology of Reptiles. $2^{\text {nd }}$ Edition. Chipping Norton. Surrey Beatty and Sons. 325 pp.

Huey, R. B. and E. R. Pianka. 1977. Seasonal variation in thermoregulatory behavior and body temperature of diurnal Kalahari lizards. Ecology 58: 1066-1075.

Huey, R. B. and M. Slatkin. 1976. Costs and benefits of lizard thermoregulation. Quarterly Review of Biology 51: $363-384$.
Kiefer, M. C., M. Van Sluys, and C. F. D. Rocha. 2007. Thermoregulatory behavior in Tropidurus torquatus (Squamata, Tropiduridae) from Brazilian coastal populations: an estimate of passive and active thermoregulation in lizards. Acta Zoologica, Stockholm 87: $81-87$.

Kohlsdorf, T. and C. A. Navas. 2006. Ecological constraints on the evolutionary association between field and preferred temperatures in Tropidurinae lizards. Evolutionary Ecology 20: 549-564.

Leal, I. R., J. M. C. Silva, M. Tabarelli, and T. E. Lacher Jr. 2005. Mudando o curso da conservação da biodiversidade na Caatinga do Nordeste do Brasil. Megadiversidade 1: $139-146$.

Magnusson, W. E. 1993. Body temperatures of the fieldactive Amazonian savanna lizards. Journal of Herpetology 27: 53-58.

Maia-Carneiro, T. and C. F. D. Rocha. 2013a. Influences of sex, ontogeny and body size on the thermal ecology of Liolaemus lutzae (Squamata, Liolaemidae) in a restinga remnant in southeastern Brazil. Journal of Thermal Biology 38: 41-46.

Maia-Carneiro, T. and C. F. D. Rocha. 2013b. Seasonal variations in behavior of thermoregulation in juveniles and adults Liolaemus lutzae (Squamata, Liolaemidae) in a remnant of Brazilian restinga. Behavioural Processes 100: $48-53$.

Maia-Carneiro, T., T. A. Dorigo, and C. F. D. Rocha. 2012. Influences of seasonality, thermal environment and wind intensity on the thermal ecology of Brazilian sand lizards in a restinga remnant. South American Journal of Herpetology 7: 241-251.

Maia-Carneiro, T., T. A. Dorigo, and C. F. D. Rocha. 2017. Seasonal influences of wind intensity on activity rates and thermoregulation of differently sized individuals of Liolaemus lutzae (Squamata: Liolaemidae). Salamandra 53: 469-472.

Martin, P. R. and P. P. G. Bateson. 2007. Measuring Behavior: An Introductory Guide. $3^{\text {rd }}$ Edition. Cambridge. Cambridge University Press. 176 pp.

Menezes, V. A. and C. F. D. Rocha. 2011. Thermal ecology of five Cnemidophorus species (Squamata: Teiidae) in east coast of Brazil. Journal of Thermal Biology 36: $232-238$.

Menezes, V. A., M. Van Sluys, A. F. Fontes, and C. F. D. Rocha. 2011. Living in a Caatinga-rocky field transitional habitat: ecological aspects of the whiptail lizard Cnemidophorus ocellifer (Teiidae) in northeastern Brazil. Zoologia 28: 8-16. 
Mesquita, D. O. and G. R. Colli. 2003. Geographical variation in the ecology of populations of some Brazilian species of Cnemidophorus (Squamata, Teiidae). Copeia 2003: 285-298.

Morgan, K. R. 1988. Body temperature, energy metabolism, and stamina in two neotropical forest lizards (Ameiva, Teiidae). Journal of Herpetology 22: 236-241.

Myers, N., R. A. Mittermeier, C. G. Mittermeier, G. A. B. Fonseca, and J. Kent. 2000. Biodiversity hotspots for conservation priorities. Nature 403: 853-858.

Oliveira Filho, A. T. and D. A. Carvalho. 1993. Florística e fisionomia da vegetação no extremo norte do litoral da Paraíba. Revista Brasileira de Botânica 16: 115-130.

Patterson, J. W. and P. M. C. Davies. 1978. Preferred body temperature: seasonal and sexual differences in the lizard Lacerta vivipara. Journal of Thermal Biology 3: 39-41.

Peloso, P. L. V., C. F. D. Rocha, S. E. Pavan, and S. L. Mendes. 2008. Activity and microhabitat use by the endemic whiptail lizard, Cnemidophorus nativo (Teiidae), in a restinga habitat (Setiba) in the state of Espírito Santo, Brazil. South American Journal of Herpetology 3: 89-95.

Pinto, C. J. B., M. U. N. Macêdo, and P. P. S. Macêdo. 2012. Plano de Manejo Floresta Nacional de Nísia Floresta Volume 1: Diagnóstico. Brasília. Ministério do Meio Ambiente. 182 pp.

Ribeiro, L. B. and E. M. X. Freire. 2010. Thermal ecology and thermoregulatory behavior of Tropidurus hispidus and T. semitaeniatus in a Caatinga area of northeastern Brazil. Herpetological Journal 20: 201-208.

Rocha, C. F. D., M. Van Sluys, D. Vrcibradic, M. C. Kiefer, V. A. Menezes, and C. C. Siqueira. 2009. Comportamento de termorregulação em lagartos brasileiros. Oecologia Brasiliensis 13: 115-131.

Sales, R. F. D. and E. M. X. Freire. 2016. Reproductive biology of a whiptail lizard (Teiidae: Ameivula) in the Brazilian Caatinga. Salamandra 52: 189-196.

Sales, R. F. D., L. B. Ribeiro, J. J. Jorge, and E. M. X. Freire. 2011. Habitat use, daily activity periods, and thermal ecology of Ameiva ameiva (Squamata: Teiidae) in a Caatinga area of northeastern. Phyllomedusa 10: 165176.
Schall, J. J. 1977. Thermal ecology of five sympatric species of Cnemidophorus (Sauria: Teiidae). Herpetologica 33: 261-272.

Sousa P. A. G. and E. M. X. Freire. 2011. Thermal ecology and thermoregulatory behaviour of Coleodactylus natalensis (Squamata: Sphaerodactylidae), in a fragment of the Atlantic Forest of northeastern Brazil. Zoologia 28: $693-700$.

Stevenson, R. D. 1985. Body size and limits to the daily range of body temperature in terrestrial ectotherms. American Naturalist 125: 102-117.

Tabarelli, M., L. P. Pinto, J. M. C. Silva, M. M. Hirota, and L. C. Bedê. 2005. Desafios e oportunidades para a conservação da biodiversidade na Mata Atlântica brasileira. Megadiversidade 1: 132-138.

Velloso, A. L., E. V. S. B. Sampaio, and F. G. C. Pareyn (eds.). 2002. Ecorregiões: Propostas para o Bioma Caatinga. Recife. Instituto de Conservação Ambiental. The Nature Conservancy do Brasil. 76 pp.

Vitt, L. J. 1995. The ecology of tropical lizards in the Caatinga of northeast Brazil. Occasional Papers of the Oklahoma Museum of Natural History 1: 1-29.

Vitt, L. J. and E. R. Pianka. 2004. Historical patterns in lizard ecology: what teiids can tell us about lacertids. Pp. 139-157 in V. Pérez-Mellado, N. Riera, and A. Perera (eds), The Biology of Lacertid Lizards: Evolutionary and Ecological Perspectives. Maó (Menorca), Illes Balears. Institut Menorquí d'Estudis.

Vitt, L. J., J. P. Caldwell, S. S. Sartorius, W. E. Cooper Jr., T. A. Baird, T. D. Baird, and V. Pérez-Mellado. 2005. Pushing the edge: extended activity as an alternative to risky body temperatures in a herbivorous teiid lizard (Cnemidophorus murinus: Squamata). Functional Ecology 19: 152-158.

Vitt, L. J., P. A. Zani, J. P. Caldwell, M. C. Araújo, and W. E. Magnusson. 1997. Ecology of whiptail lizards (Cnemidophorus) in the Amazon region of Brazil. Copeia 1997: 745-757.

Vrcibradic, D. and C. F. D. Rocha. 1998. The ecology of the skink Mabuya frenata in an area of rock outcrops in southeastern Brazil. Journal of Herpetology 32: 229237.

Editor: Carlos A. Navas 
Appendix I. Ethogram of whiptail lizards Ameivula ocellifera made through focal observations in three populations in the state of Rio Grande do Norte, northeastern Brazil, two in Caatinga and one in Atlantic Forest.

\begin{tabular}{ll}
\hline Behavioral category & \multicolumn{1}{c}{ Description } \\
\hline $\begin{array}{l}\text { Foraging - visual and chemosensory } \\
\text { search }\end{array}$ & $\begin{array}{r}\text { Lizard stationary or moving, with the head pointing to several directions, often } \\
\text { tongue-flicking substrates and air. When moving, the displacement is usually } \\
\text { intermittent, with breaks of one-hundredths of a second. }\end{array}$ \\
\hline $\begin{array}{l}\text { Foraging - digging or revolving } \\
\text { substrate }\end{array}$ & $\begin{array}{r}\text { Lizard digging sand or twirling leaves and branches with fore limbs and snout. } \\
\text { When exhibiting this behavior, lizards usually become stationary, but occasionally } \\
\text { walk to remove sand, branches or leaves with their limbs from the digging site. }\end{array}$ \\
\hline Foraging - prey handling & $\begin{array}{r}\text { Lizard performing subjugation and ingestion of captured prey. They can be } \\
\text { stationary or moving with the prey in the mouth. }\end{array}$ \\
\hline $\begin{array}{l}\text { Lizard stationary with head raised, or moving at high speed, usually after some } \\
\text { predator approaching, wind noise, or when the animal moves from one patch } \\
\text { of vegetation to another. Lizards do not tongue-flick the substrate or air when } \\
\text { vigilant, and they might eventually wave their tails, blink the eyes or perform head } \\
\text { bobbings. This behavioral category is related to vigilance against predators, but } \\
\text { also possibly serve as passive visual search for prey. }\end{array}$
\end{tabular}

Lizard stationary with the head propped on the substrate or slightly inclined, and the fore and hind limbs resting with the toes in contact with the ground or raised in Basking direction to the luminosity, so that the animal rests on his wrists and ankles. Some basking animals eventually slowly blink lethargically and open widely the mouth, similar to a yawn. Lizards usually exhibit this behavior in areas with direct solar incidence or when the sun is overcast over long periods of time.

Social interactions include both agonistic encounters and reproductive behavior. Agonistic encounters usually result in chases arising from conspecific approaches;

Social interactions in solitary individuals, they occur between two adult males, between two adult

females, between males and females or between an adult and a juvenile. In couples, agonistics interactions usually occur between the male companion and another male trying to approach the accompanied female.

Other behaviors

Behavioral events that occur at low frequency and last for a few seconds, such as scratching the body with the front or back limbs, and defecating. 
Appendix II. Behaviors of exposure to sunlight in populations of Ameivula ocellifera in the state of Rio Grande do Norte, northeastern Brazil. (A) Direct sunlight; (B) filtered sunlight; $(\boldsymbol{C})$ shade; (D) cloudy conditions. Photographs A, B, and C were taken in the Atlantic Forest and photograph $\boldsymbol{D}$ is from disturbed Caatinga.

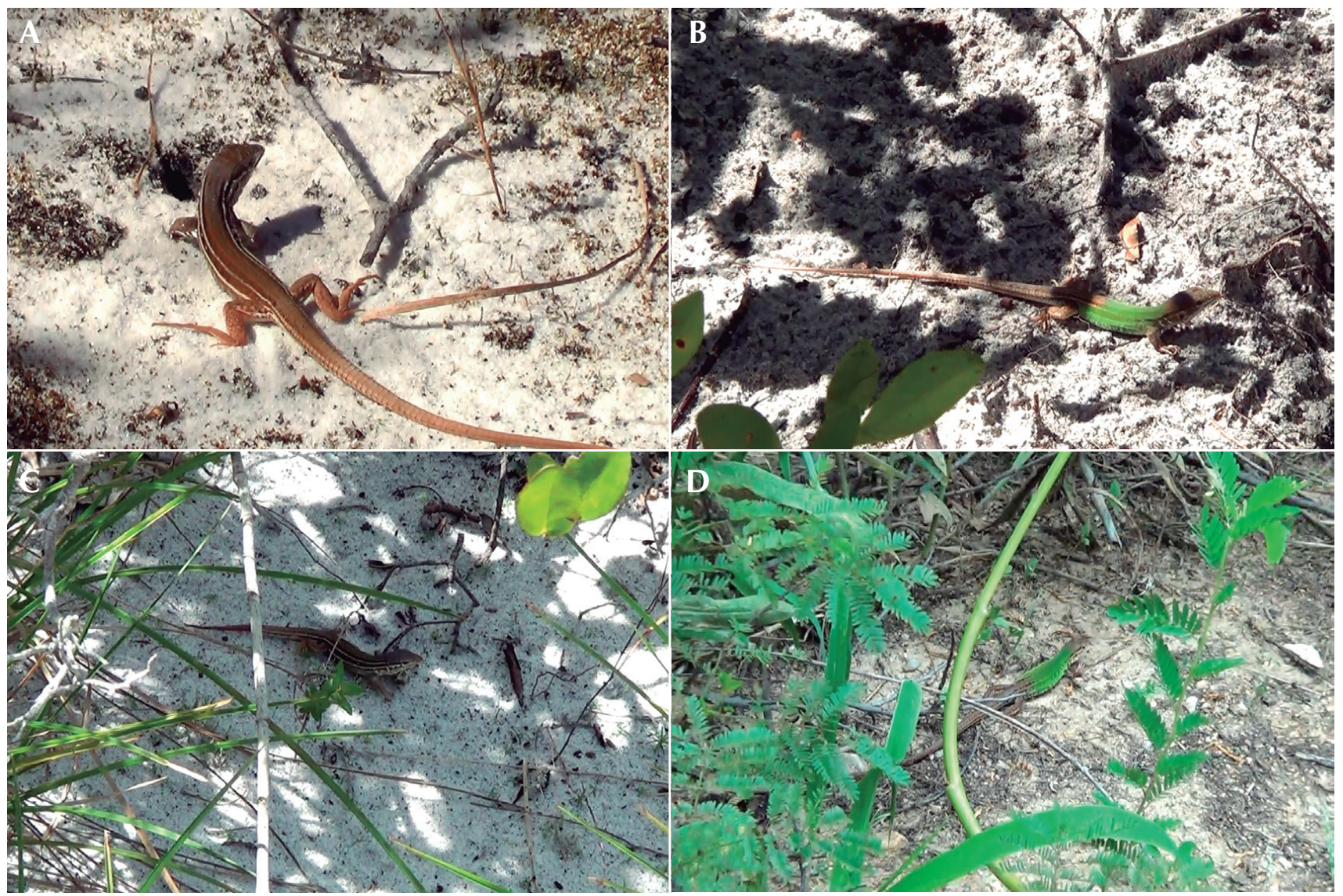


Appendix III. Basking behaviors of Ameivula ocellifera in the state of Rio Grande do Norte, northeastern Brazil.

(A) Individual basking during cloudy conditions; (B-D) lizards basking exposed to direct sunlight.

Note the entire ventral surfaces contacting substrates in $A, B$ and $C$, eyes closed in $B$, limbs raised to the air in $C$, and mouth open in D. Photographs $A$ and $C$ were taken in disturbed Caatinga, photograph $B$ is from natural Caatinga, and photograph $D$ is from Atlantic Forest.

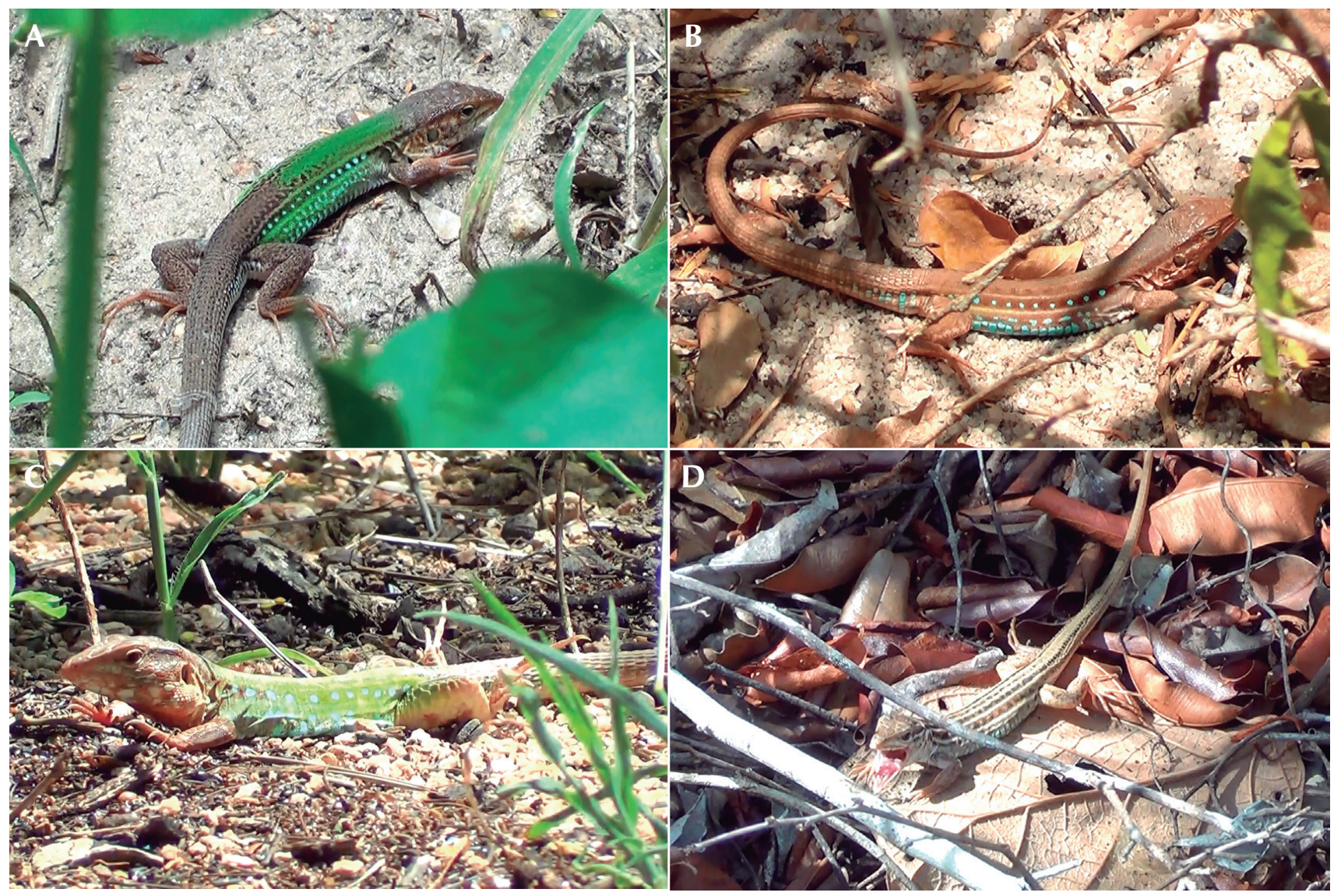

